\title{
Diaporthe pseudolongicolla - the new pathogen on soybean seed in Serbia
}

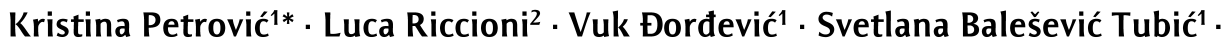 \\ Jegor Miladinović ${ }^{*}$ Marina Ćeran ${ }^{1}$. Dragana Rajković
}

${ }^{1}$ Institute of Field and Vegetable Crops, Maksima Gorkog 30, 21000 Novi Sad, Serbia

${ }^{2}$ CREA - Council for Agricultural Research and Agricultural Economics Analysis, Plant Pathology Research Centre Via Po, 14 - 00198 Roma, Italy

\begin{abstract}
Summary: Seed decay is one of the most important diseases of soybean (Glycine max (L.) Merr.) that has a negative impact on the market grade of soybeans. The disease is mainly caused by Diaporthe longicolla, along with other Diaporthe species. Screening of soybean seeds health status in Vojvodina Province, Serbia, showed cultural and morphological variability among isolates identified as $D$. longicolla. With the use of DNA sequences of internal transcribed spacer (ITS1-5.8S-ITS2) region and partial translation elongation factor 1-alpha (EF1- $\alpha$ ), the new species was determined. BLAST analysis showed $100 \%$ identity with $D$. pseudolongicolla (syn. D. novem) that was described in this study and its taxonomic revision is discussed. Pathogenicity trial showed that both species, D. longicolla and D. pseudolongicolla, are highly pathogenic on soybean stem and seed, causing $100 \%$ of stem wilting and more than $82 \%$ of seed decay.

Key words: D. Longicolla, D. pseudolongicolla, Diaporthe, seed decay, soybean
\end{abstract}

\section{Introduction}

Soybean (Glycine max (L.) Merr.) is listed as the second most significant oil crop, just after oil palm (FAO, 2014). It occupies prominent position with the highest protein level among legumes. Soybean is used for livestock feeding, as edible and industrial oil, as well as high protein food crop for human consumption. More than 200 phytopathogenic microorganisms have been described on soybean (Hartman et al. 2015). Most of them attack soybean seed and thus negatively affect germination and seed quality. One of the major causes of poor seed quality in most soybean-growing regions worldwide is seed decay. It is caused primary by Diaporthe longicolla, along with $D$. sojae, D. caulivora, D. aspalathi, $D$. eres species complex, $D$. foeniculina, and $D$. rudis (Li, 2011; Petrović et al., 2015; Petrović et al. 2016). Soybean seeds infected with Diaporthe species are usually small, shrunken, flattened and elongated, with cracked seed coats and chalky-white mycelium (Fig 1).

Corresponding author:

kristina.petrovic@ifvcns.ns.ac.rs

Acknowledgment:

This study was funded by the Ministry of Education, Science and Technological Development of the Republic of Serbia, under the project TR31022.
This has negative influence on the market grade of soybeans. On the other hand, latent infected seeds have a normal appearance, without symptoms of disease, but with reduced germination, vitality and quality (Kmetz, Schmitthenner \& Ellett, 1978).

In the 1980s and 1990s, causal agents of seed decay were distinguished based on the symptomatological, morphological, cultural and pathogenic characteristics (Hobbs, Schmitthenner \& Kuter, 1985; Morgan-Jones, 1989; Sinclair, 1993). In many Diaporthe species, both anamorph (asexual) and teleomorph (sexual) stages have been described as well as their ability to form pycnidia and perithecia. However, D. longicolla has long been described as a fungus without the teleomorph stage whose pycnidia have very long necks that release only alpha conidia. Recent studies revealed new details on this fungus such as atypical symptoms on stems in the field, pycnidia with beta conidia and the ability to form teleomorph (Santos, Vrandečić, Ćosić, Duvnjak \& Phillips, 2011; Vidić et al. 2013; Olson et al. 2015).

During monitoring of soybean seeds health status in Vojvodina province, Serbia, slight differences among $D$. longicolla isolates were noticed. Detailed molecular study showed the presence of new species. For this reason, study of a new parasite and its possible pathogenicity on the soybean has been described in this paper as well as its taxonomical relation to $D$. longicolla. 

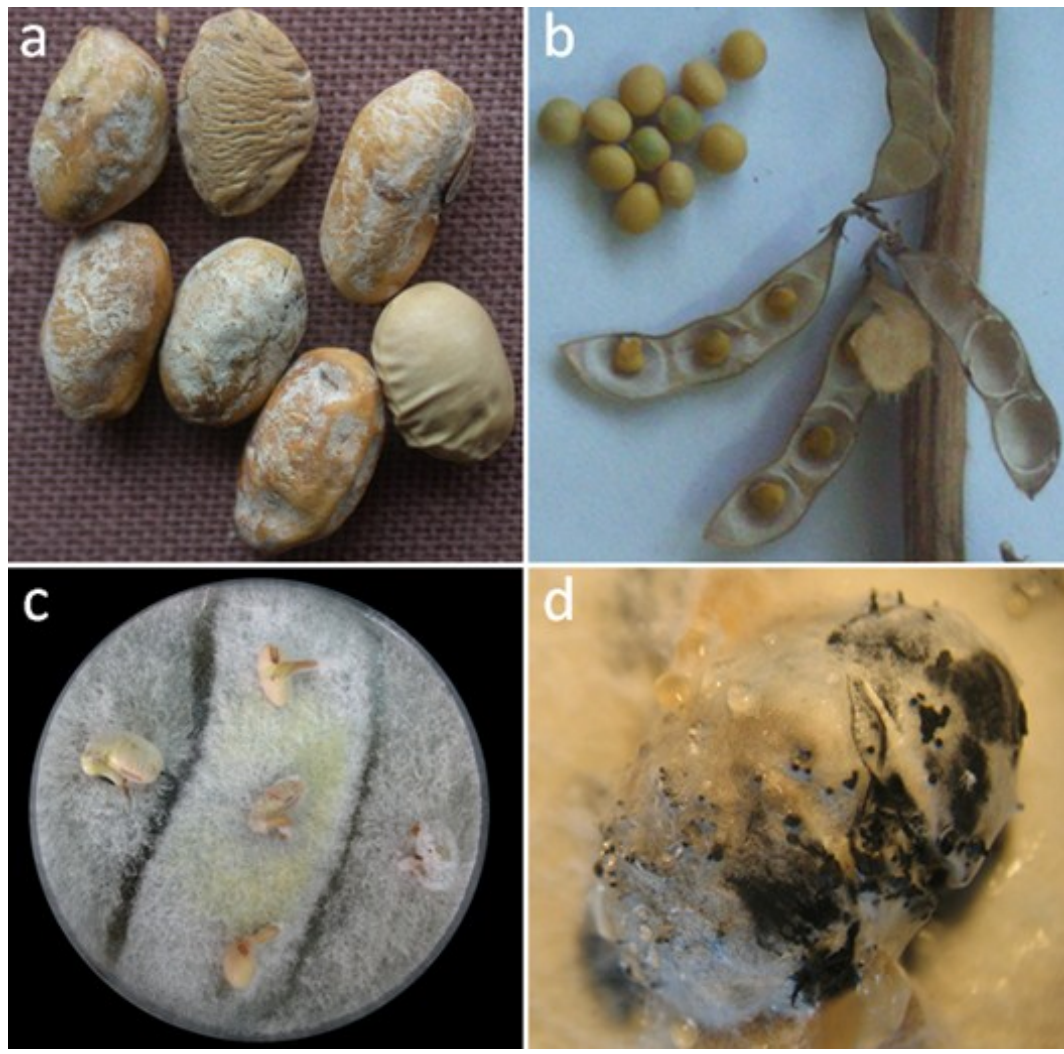

Figure 1. Seed decay. a-b: rotten seeds, c: latently infected seeds, d: stroma with pycnidia on soybean seed

\section{Materials and Methods}

\section{Isolation and morphology}

Symptomatic plants and seeds were collected throughout the soybean-producing area in Vojvodina Province, Serbia in period 2002-2012. Using standard phytopathological procedures $64 \mathrm{D}$. longicolla singleconidial isolates were obtained, 33 from seeds and 31 from diseased stem tissues. A total of 64 isolates were confirmed on potato-dextrose agar (PDA), while the sporulation of representative isolates was monitored during two months on PDA with 5-cm-long pieces of autoclaved soybean stems. Morphological features (pycnidial conidiomata, alpha and beta conidia) were described and measured (100 conidia and pycnidial conidiomata).

\section{Sequence Analysis}

DNA was extracted from all isolates using modified protocol of Cenis (1992). PCR (Polymerase Chain Reaction) amplification, sequencing of the internal transcribed spacer (ITS1-5.8S-ITS2) region of rDNA and partial translation elongation factor 1-alpha (EF1- $\alpha)$ were performed as described by Vidić et al. (2013). BLAST searches were carried out to select closely related sequences from GenBank. Using ITS identification, representative isolates were selected for sequencing of EF1- $\alpha$ and further morphological and pathogenic characterization (Table 1).

\section{Pathogenicity testing}

Pathogenicity of selected isolates was tested on soybean cultivar Sava, plants and seeds. Soybean plants were cultivated in the greenhouse: five plants per pot in four replications. Plants were inoculated at V2 growth stage according to the plug method by Vidić et al. (2013), while conidial suspensions $\left(10^{6}\right.$ conidia/ml $)$ were used in seed test inoculation following the method by Vidić et al. (2013). Seeds, inoculated with each isolate, were placed on wet filter paper in $90 \mathrm{~mm}$ Petri dishes, 25 seeds per dish. The experiment was set up in four replications and incubation was at $24^{\circ} \mathrm{C}$. After seven days, number of decayed germinated and ungerminated seeds was counted. The significance of differences between obtained data was tested by ANOVA, using the Dunnett's test.

\section{Results and Discussion}

\section{Morphological characteristics}

Using morphological profile given by Hobbs et al. (1985), cultural and morphological differences among isolates that were previously identified as $D$. longicolla were noticed. Both, D. longicolla (Fig 2) and D. pseudolongicolla (Fig 3) had similar appearance in Petri dishes. White, compact mycelia with yellowish-green ring around the centre of the colony were a typical feature for both species. Inside of their black stromatic structure pycnidial conidiomata with alpha conidia and 
Table 1. List of representative isolates of $D$. longicolla and $D$. pseudolongicolla used in this study

\begin{tabular}{|c|c|c|c|c|c|c|}
\hline \multirow[t]{2}{*}{ Species } & \multirow[t]{2}{*}{ Isolate } & \multirow{2}{*}{$\begin{array}{l}\text { Source of } \\
\text { isolation }\end{array}$} & \multirow[t]{2}{*}{ Origin } & \multirow[t]{2}{*}{ Collector } & \multicolumn{2}{|c|}{$\begin{array}{c}\text { GenBank accession } \\
\text { numbers }\end{array}$} \\
\hline & & & & & ITS & EF1- $\alpha$ \\
\hline \multirow{2}{*}{ Diaporthe longicolla } & & stem & $\begin{array}{l}\text { Rimski } \\
\text { Šančevi }\end{array}$ & Vidić M. & JQ697845 & JQ697858 \\
\hline & PL/KR19 & seed & $\begin{array}{l}\text { Rimski } \\
\text { Šančevi }\end{array}$ & Petrović K. & JF430483 & JF461469 \\
\hline \multirow{5}{*}{$\begin{array}{l}\text { Diaporthe pseudolongicolla } \\
\text { (syn. D. novem) }\end{array}$} & PL42 & seed & Loznica & Vidić M. & JQ697843 & JQ697856 \\
\hline & PL44 & seed & Žabalj & Vidić M. & KU672724 & KU672725 \\
\hline & PL68 & seed & Sombor & Petrović K. & JQ697842 & JQ697855 \\
\hline & PL75 & seed & Subotica & Petrović K. & JQ697841 & JQ697854 \\
\hline & PL/KR6 & seed & Ruma & Petrović K. & JF704181 & JF704182 \\
\hline
\end{tabular}
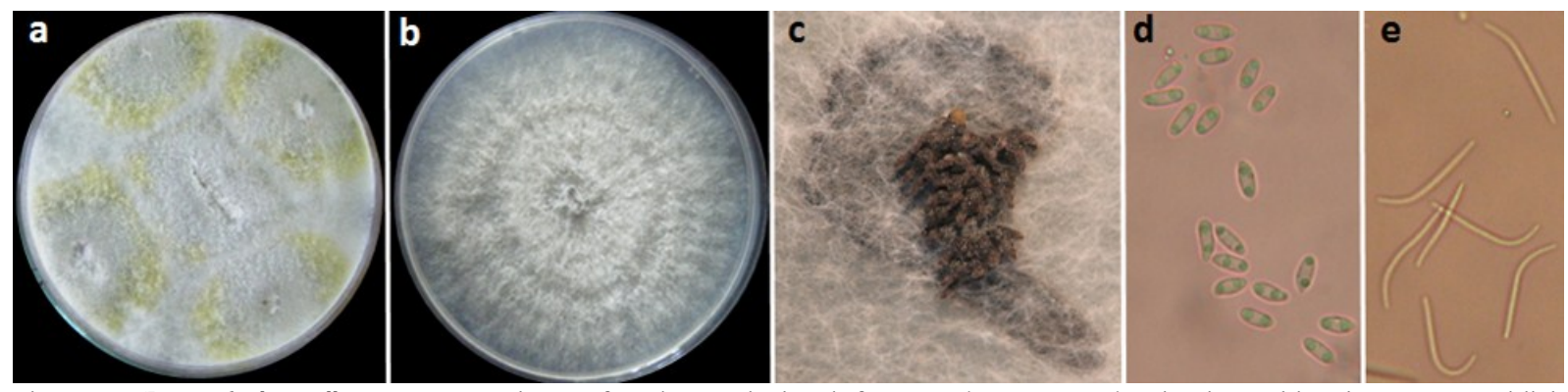

Figure 2. Diaporthe longicolla. a: young colony of pathogen isolated from soybean stem, b: six days old colony, c: pycnidial conidiomata on stroma, d: alpha conidia, e: beta conidia
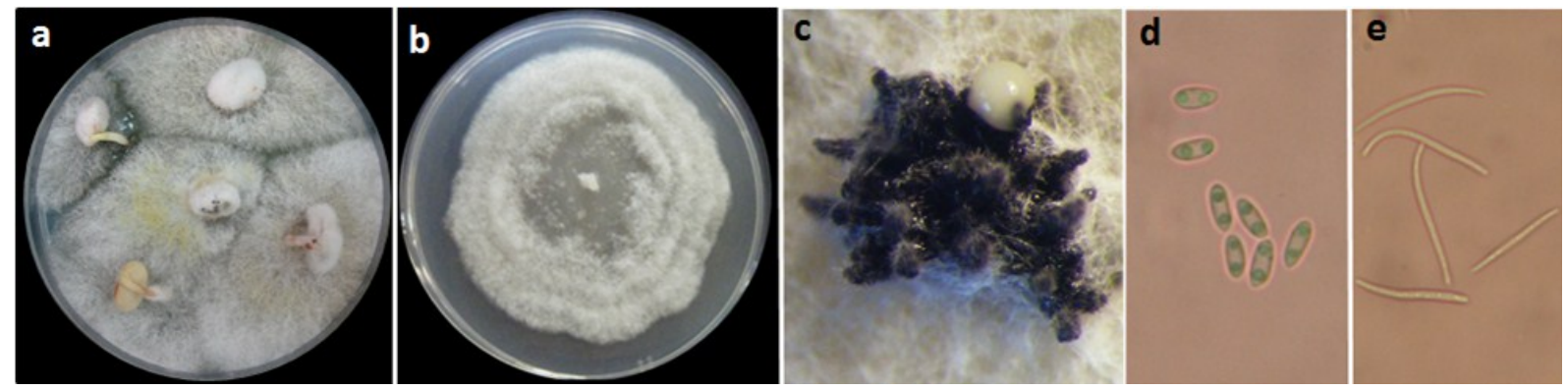

Figure 3. Diaporthe psendolongicolla. a: young colony of pathogen isolated from soybean seeds, b: six days old sterile colony, c: pycnidial conidiomata on stroma, d: alpha conidia, e: beta conidia

rarely beta conidia were observed. Both species lacked of perithecia. The only observed difference among them was that $D$. pseudolongicolla isolates rapidly became sterile and lost their ability to form reproductive organs.

\section{Identification}

At the time of the morphological identification concept, it was believed that only Diaporthe species present on soybean seeds were $D$. longicolla, D. sojae, $D$. caulivora and D. aspalathi (Morgan-Jones, 1989; Sinclair, 1993). However, in the most studies at that time, the variability of Diaporthe species was reported in terms of morphological characteristics, which led many authors to conclusion that there exist more Diaporthe species among well-known pathogens (Fernández \& Hanlin, 1996; Zhang et al., 1997; Zhang et al. 1998; Zhang, Hartman, Curio-Penny, Pedersen \& Becker, 1999; Li,
2011). Introduction of molecular tools helped to resolve variability among Diaporthe isolates from soybean and was beneficial in detection of new species (Santos et al., 2011; Petrović et al. 2015; 2016; Mathew, Gulya, Jordahl \& Markell, 2018). Using ITS sequences, from a total of 64 isolates, 59 strains were identified as D. longicolla, while five strains were separated as a new species named D. pseudolongicolla (Table 2). These five strains were previously determined as $D$. longicolla by morphological identification concept. All 59 D. longicolla isolates had uniform ITS and EF1- $\alpha$ sequences, and PDS157A and PL/KR19 were designated as reference isolates of $D$. longicolla. Isolates of $D$. longicolla were equally present on soybean seeds and stems, while $D$. pseudolongicolla was isolated only from seeds. Symptoms of seed decay produced by both species were identical and causal agents could not be visually identified. Newly 
Table 2. Identification of D. longicolla and D. pseudolongicolla isolates by the BLAST analysis

\begin{tabular}{|c|c|c|c|c|c|}
\hline \multirow{2}{*}{ Locus } & \multirow{2}{*}{ Isolate } & \multicolumn{2}{|c|}{ Diaporthe longicolla } & \multicolumn{2}{|c|}{ Diaporthe pseudolongicolla } \\
\hline & & Type sequence ${ }^{\mathrm{a}}$ & $\%$ of identity & Type sequence ${ }^{\mathrm{a}}$ & $\%$ of identity \\
\hline \multirow{7}{*}{ ITS1-5.8S-ITS2 } & PDS157A & \multirow{7}{*}{$\begin{array}{l}\text { CBS127267 } \\
\text { (HM347700) }\end{array}$} & 100 & \multirow{7}{*}{$\begin{array}{l}\text { CBS117165 } \\
\text { (DQ286285) }\end{array}$} & 96 \\
\hline & PL/KR19 & & 100 & & 96 \\
\hline & PL42 & & 96 & & 100 \\
\hline & PL44 & & 96 & & 100 \\
\hline & PL68 & & 96 & & 100 \\
\hline & PL75 & & 96 & & 100 \\
\hline & PL/KR6 & & 96 & & 100 \\
\hline \multirow{7}{*}{ EF1- $\alpha$} & PDS157A & \multirow{7}{*}{$\begin{array}{c}\text { CBS127267 } \\
\text { (HM347685) }\end{array}$} & 100 & \multirow{7}{*}{$\begin{array}{l}\text { CBS117165 } \\
\text { (DQ286259) }\end{array}$} & 71 \\
\hline & PL/KR19 & & 100 & & 71 \\
\hline & PL42 & & 70 & & 100 \\
\hline & PL44 & & 70 & & 100 \\
\hline & PL68 & & 70 & & 100 \\
\hline & PL75 & & 71 & & 100 \\
\hline & PL/KR6 & & 70 & & 100 \\
\hline
\end{tabular}

a CBS, The Centraalbureau voor Schimmelcultures, Utrecht, the Netherlands

detected species was probably present on soybean seeds for a long time masked by well-known seedborne pathogens.

\section{Taxonomy}

Diaporthe longicolla (Hobbs) J.M. Santos, Vrandečić \& A.J.L. Phillips, Persoonia 27: 13. 2011. (Fig 2)

Basionym. Phomopsis longicolla Hobbs, Mycologia 77: 542. 1985.

Cultural characteristics: On PDA had white, compact aerial mycelium with typical yellowish-green ring around the centre of the colony. After 5-7 days, colony formed massive, black stromatic structures, irregular in shape, which completely covered the bottom of Petri dishes.

Pycnidial conidiomata on autoclaved soybean stem with PDA in culture were globose, black, aggregated and rarely solitary. They had long necks, ranging 250-700 $\mu \mathrm{m}$ in length. Pycnidia formed within black stroma had white to yellowish mucous droplets observed on ostiole. Alpha conidia were ellipsoidal, 2-guttules, dimensions 4.9$7.5 \times 2.2-3.0 \mu \mathrm{m}$. Beta conidia were found in two-months -old cultures. They were unicellular, comma-shaped, size 22.3-29.2 × 1.0-1.3 $\mu \mathrm{m}$.

Perithecia were not formed.

Notes - Pycnidia formed into black zone line symptoms (Vidić et al. 2013) on the lower part of the soybean stem, were always releasing alpha and beta conidia. Santos et al. (2011) reported that D. longicolla possesses both mating-types indicating that this species is selffertile. Moreover, Vidić et al. (2013) have found several perithecia on overwintered stems inoculated with isolate PDS157A. The perithecial body varied in size from 117 to $406 \mu \mathrm{m}$ in diameter, with the average $234 \mu \mathrm{m}$ (Vidić, unpublished data). Asci and ascospores were typical for the genus Diaporthe, but perithecia were never found in culture. However, authors were not successful in repeating the trial and proving presence of the perithecia of $D$. longicolla. On the other hand, Fernández and
Hanlin (1996) noted that one isolate (PI 526), morphologically identified as $D$. lonigicolla produced few fertile perithecia only when grown on autoclaved elm bark, but they were also not able to repeat that finding. Known hosts - Abutilon theophrasti (Li, Bradley, Hartman \& Pedersen, 2001; Vrandečić et al. 2004), Acer truncatum (Sun, Guo \& Hyde, 2011), Amaranthus spinosus and Leonorus sibiricus (Cerkauskas, Dhingra, Sinclair \& Asmus, 1983), Ambrosia trifida, Euphorbia maculata, Rumex crispus, Xanthium strumarium and Vigna unguiculata (Roy, Ratnayake \& McLean, 1997), Arachis bypogaea (Sanogo \& Etarock, 2009), Aster exilis, Caperonia palustris, Desmanthus illinoensis, Eclipta prostrata, Euphorbia nutans, Ipomoea lacunose, Polygonum aviculare and Sida spinosa (Mengistu \& Reddy, 2005), Chamaesyce nutans (Mengistu, Castlebury, Smith, Rossman \& Reddy, 2007), Cucumis melo, Glycine max (Hobbs et al. 1985; Vidić, Jasnić \& Stojšin, 1996; Zhang et al. 1997; Santos et al. 2011; Gomes et al. 2013), Helianthus annuus (Mathew et al. 2012), Pyrus pyrifolia (Bai et al. 2015), Solanum melongena (Shu et al. 2014), and Trichilia elegans (Flores, Pamphile, Sarragiotto \& Clemente, 2013).

Distribution - Argentina (Hernandez, Pioli, Peruzzo, Formento \& Pratta, 2015), Australia (Ash et al. 2010), China (Cui, Duan, Wang, Li \& Zhu, 2009; Shu, Chen, Huang, He \& Zhou, 2014), Croatia (Vrandečić et al. 2004), Greece (Holevas et al. 2000), New Mexico (Sanogo \& Etarock, 2009), Serbia (Vidić \& Jasnić, 1994) and USA (Hobbs et al. 1985; Zhang et al. 1997).

Diaporthe pseudolongicolla, K. Petrović, L. Riccioni \& M. Vidić, nom. nov. - MycoBank MB564245 (Fig 3);

Etymology: The prefix psendo is used to mark very similar fungus with $D$. longicolla in terms of morphological and pathogenic features.

$=$ D. novem, J.M. Santos, Vrandečić \& A.J.L. Phillips, Persoonia 27: 14. 2011. 
Basionym. Phomopsis sp. 9 (van Rensburg et al. 2006)

Cultural characteristics: Fresh strains were identical with $D$. longicolla in terms of white, compact aerial mycelia on PDA. Main difference between these two species was that isolates of $D$. pseudolongicolla quickly become sterile and lost ability to produce reproductive organs.

Pycnidial conidiomata on autoclaved soybean stems with PDA in culture were sphaerical, up to $550 \mu \mathrm{m}$ in diameter. They were black, aggregated within stroma, without necks or with long necks, up to $450 \mu \mathrm{m}$ long. Yellowish drop with alpha and beta conidia exuded from the ostiole. Alpha conidia were unicellular, bi- to multiguttulate, ellipsoidal with dimension 6.2-9.7 $\times 2.3$ $3.1 \mu \mathrm{m}$. Beta conidia were unicellular, filiform, curved at one end, size 19.5-29.1 × 0.9-1.2 $\mu \mathrm{m}$ and rarely formed. Perithecia were not formed.

Notes - The reference isolate Phomopsis sp. 9 could not be determined, because it was sterile when deposited in the CBS collection, and marked by numerological classification system (van Rensburg, Lamprech,
Groenewald, Castlebury \& Crous, 2006). Later, Santos et al. (2011) proposed the formal name D. novem, but the problem of numerological classification remained (novem $=$ nine, Latin $)$. Numerology classification system cannot be considered as valid, since it provides only temporary solution during identification of an organism. For that reason, the name of $D$. novem appears to be incorrect, because it is not in consistence with the Code of classification (http://www.iapttaxon.org $/$ nomen $/$ main.php?page=art23). Moreover, Santos et al. (2011) have established that D. novem is a heterothallic fungus, which means that perithecia will form only when the isolates with opposite mating type were crossed and this is the reason why perithecia are rarely observed. Since strong similarity in terms of morphological characteristics as well as pathogenicity was observed among D. longicolla and Phomopsis sp. 9 (syn. D. novem) isolates, it is considered that Diaporthe pseudolongicolla (MB564245) is appropriate name for the unidentified group Phomopsis sp. 9 (Petrović, 2012).

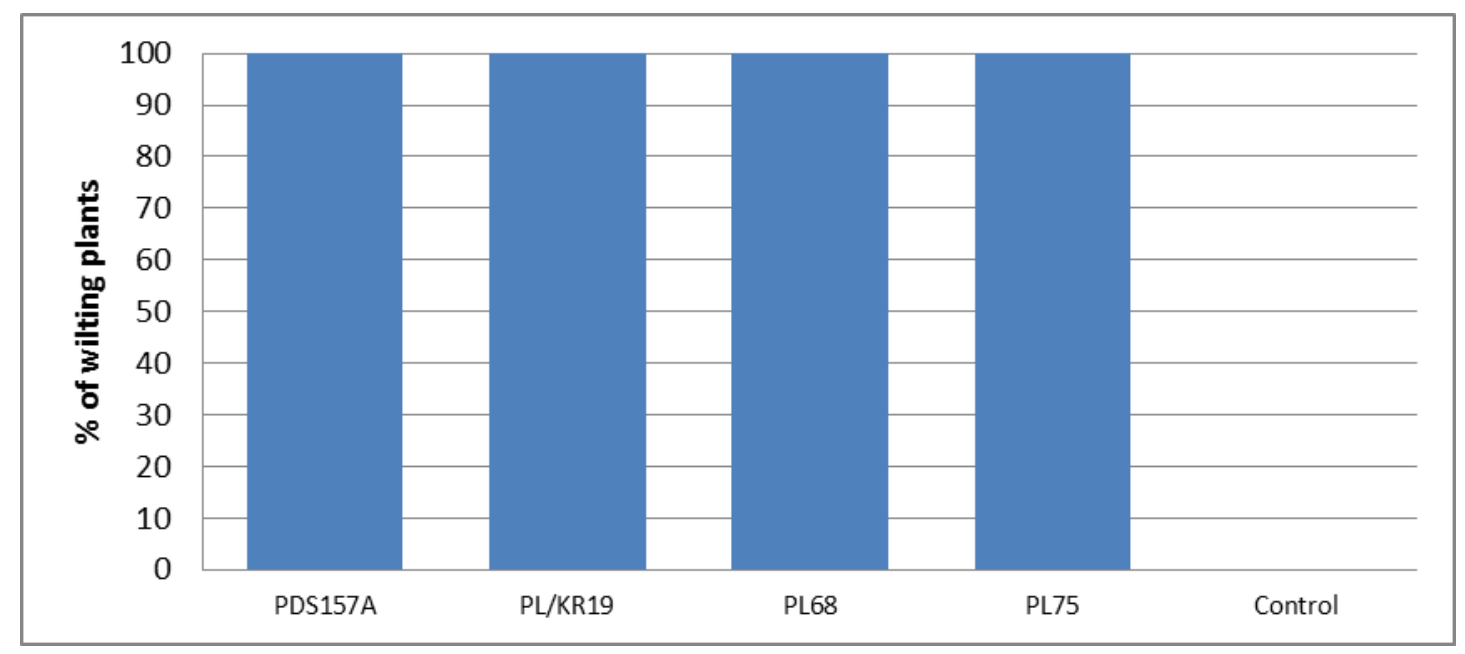

Figure 4. Pathogenicity of D. longicolla and D. pseudolongicolla isolates on soybean plants

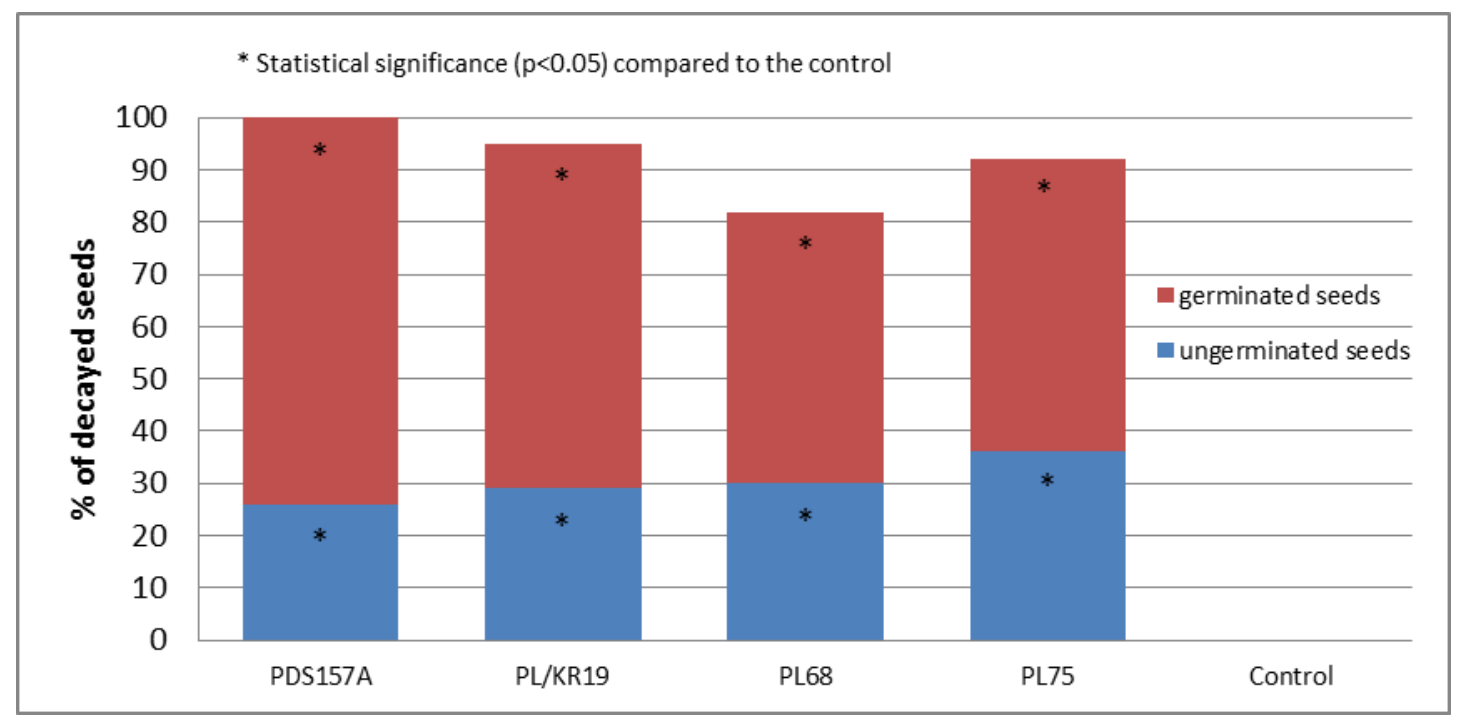

Figure 5. Pathogenicity of D. Longicolla and D. pseudolongicolla isolates on soybean seeds 
Known hosts - Asclepias syriaca, Aspalathus linearis (van Rensburg et al. 2006), Actinidia deliciosa (Díaz et al. 2014), Glycine max, Helianthus annuus (Rekab, Del Sorbo, Reggio, Zoina \& Forrao, 2004), Hydrangea macrophylla (Santos, Correia \& Phillips, 2010), and Vitis vinifera (van Niekerk et al. 2005).

Distribution - Chile (Díaz et al. 2014), Croatia (Santos et al. 2011), Italy (Rekab et al. 2004), Portugal (Santos et al. 2010), South Africa (van Niekerk et al. 2005; van Rensburg et al. 2006).

\section{Pathogenicity testing}

Both species had high degree of virulence on soybean plants causing 100\% wilting (Fig 4). The plug method of inoculation managed to reproduce the typical symptoms of pod and stem blight on soybean stem. In the beginning, pycnidial lesions were visible near the injection site. Later on, pycnidia spread up and down along the stem. Inoculation of soybean seeds by immersing them into conidia suspension showed that $D$. longicolla and $D$. pseudolongicolla significantly reduced the germination rate of the seeds compared to the control. Results showed that D. longicolla isolates PDS157A and PL/KR19 caused $100 \%$ of seed decay, while $D$. pseudolongicolla isolates PL68 and PL75 caused 82\% and $92 \%$ of seed decay, respectively (Fig 5). Control plants and seeds were symptomless. Pathogenicity of $D$. longicolla isolates on soybean stems and seeds were observed by Vidić et al. (2013), who noted variability in aggressiveness, but pathogenicity data of $D$. pseudolongicolla was missing and this study represents the first results of pathogenicity of this species on soybean.

\section{Conclusion}

Diaporthe species are one of the major causes of soybean seed decay and the most aggressive is $D$. longicolla along with $D$. pseudolongicolla. The difference between these two species is that isolates of $D$. pseudolongicolla rapidly became sterile when grown in culture and lost their ability to form reproductive organs. Using ITS and EF1- $\alpha$ sequences, from a total of 64 isolates, 59 strains were identified as D. longicolla, while five strains separated as a new species named $D$. pseudolongicolla. Isolates of $D$. longicolla were equally present on soybean seeds and stems, while $D$. pseudolongicolla was isolated only from seeds. Isolates of D. longicolla PDS157A and PL/KR19 caused 100\% of seed decay, while D. pseudolongicolla isolates PL68 and PL75 caused $82 \%$ and $92 \%$ of seed decay, respectively. This study represents the first result of pathogenicity of D. pseudolongicolla on soybean.

\section{References}

Ash, G.J., Stodart, B., Sakuanrungsirikul S, Anschaw, E., Crump, N., Hailstones, D. \& Harper, J. D. I. (2010). Genetic characterization of a novel Phomopsis sp., a putative biocontrol agent for Carthamus lanatus. Mycologia, 102: 54-61.
Bai, Q., Zhai, L.F., Chen, X.R., Hong, N., Xu, W.X. \& Wang, G.P. (2015). Biological and molecular characterization of five Phomopsis species associated with pear shoot canker in China. Plant Disease, 99: 1704-1712.

Cenis, J.L. (1992). Rapid extraction of fungal DNA for PCR amplification. Nucleic Acids Research, 20: 2380.

Cerkauskas, R.F., Dhingra, O.D., Sinclair, J.B. \& Asmus, G. (1983). Amarabthus spinosus, Leonotis nepetaefolia, and Leonorus sibiricus: New hosts for Phomopsis spp. in Brazil. Plant Disease, 67: 821- 824.

Cui, Y.L., Duan, C.X., Wang, X.M., Li, H.J. \& Zhu, Z.D. (2009). First report of Phomopsis longicolla causing soybean stem blight in China. Plant Pathology, 58: 799.

Díaz, G.A., Latorre, B.A., Jara, S., Ferrada, E., Naranjo, P., Rodríguez, J. \& Zoffoli, J.P. (2014). First report of Diaporthe novem causing postharvest rot of kiwifruit during controlled atmosphere storage in Chile. Plant Disease, 98: 1274.

Food and Agriculture Organization of the United Nations (2014). FAOSTAT. Available at www.fao.org/faostat/ en/. Accessed Mai 29, 2018. Fernández, F. A. \& Hanlin, R. T. (1996). Morphological and RAPD analyses of Diaporthe phaseolorum from soybean. Mycologia, 88: 425440.

Flores, A.C., Pamphile, J.A., Sarragiotto, M.H. \& Clemente, E, (2013). Production of 3-nitropropionic acid by endophytic fungus Phomopsis longicolla isolated from Trichilia elegans A. JUSS ssp. elegans and evaluation of biological activity. World Journal of Microbiology and Biotechnology, 29: 923-932.

Gomes, R., Glienke, C., Videira, S., Lombard, L., Groenewald, J. \& Crous P (2013). Diaporthe: a genus of endophytic, saprobic and plant pathogenic fungi. Persoonia, 31:1-41.

Hartman, G.L., Rupe, J.C., Sikora, E.J., Domier, L.L., Davis, J.A. \& Steffey, K.L. (2015). Compendium of soybean diseases and Pests, Fifth edition St. Paul, Minnesota, USA: APS Press.

Hernandez, F.E., Pioli, R.N., Peruzzo, A.M., Formento, Á.N. \& Pratta, G.R. (2015). Morphologic and molecular characterization of Phomopsis longicolla (teleomorph unknown, Diaporthales) from tempered and subtropical regions of Argentina. Revista de Biologia Tropical, 63: 871-884.

Hobbs, T.W., Schmitthenner, A.F. \& Kuter, G.A. (1985) A new Phomopsis species from soybean. Mycologia, 77: 535-544.

Holevas, C.D., Chitzanidis, A., Pappas, A.C., Tzamos, E.C., Elena, K., Psallidas, P.G.,... Varveri, C. (2000) Disease agents of cultivated plants observed in Greece from 1981 to 1990. Annales de l'Institut Phytopathologique Benaki, 19: 1- 96.

Kmetz, K.T., Schmitthenner, A.F. \& Ellett, C.W. (1978). Soybean seed decay: Prevalence of infection and symptom expression caused by Phomopsis sp., Diaporthe phaselorum var. caulivora. Phytopathology, 68: 836-840.

Li, S. (2011). Phomopsis seed decay of soybean, In: A. Sudarić, (Ed.) Soybean-Molecular Aspects of Breeding (pp. 277-292). Vienna, Austria: InTech doi: 10.5772/15688.

Li, S., Bradley, C.A., Hartman, G.L. \& Pedersen, W.L. (2001). First report of Phomopsis longicolla from velvetleaf causing stem lesions on inoculated soybean and velevetleaf plants. Plant Disease, 85: 1031.

Mathew, F., Alananbeh, K., Balbyshev, N., Heitkamp, E., Castlebury, L., Gulya, T. \& Markell, S. (2012). Reevaluation of Phomopsis species affecting sunflowers in the United States. In: Proceedings of the 18th International Sunflower Conference ( $\mathrm{p}$ 74). Mar del Plata, Argentina, 1.

Mathew, F., Gulya, T., Jordahl, J. \& Markell, S. (2018). First report of stem disease of soybean (Glycine max) caused by Diaporthe gulyae in North Dakota. Plant Disease, 102: 240.

Mengistu, A., Castlebury, L.A., Smith, J.R., Rossman, A.Y.\& Reddy, K.N. (2007). Isolates of Diaporthe-Phomopsis from weeds and their effect on soybean. Canadian Journal of Plant Pathology, 29: 283-289. 
Mengistu, A. \& Reddy, K.N. (2005). Detection of Phomopsis spp. on weed hosts and its pathogenicity on soybean. Seed Technology, 27: 97- 100 .

Morgan-Jones, G. (1989). The Diaporthe/Phomopsis complex: taxonomic considerations, In: A. Pascale (Ed.), Proceedings of the World Soybean Research Conference IV, (pp. 1699-1706). Buenos Aires, Argentina, Editora Orientación Gráfica,.

Olson, T.R., Gebreil, A., Micijevic, A., Bradley, C.A., Wise, K.A., Mueller, D.S.,...Mathew, F.M. (2015). Association of Diaporthe longicolla with black zone lines on mature soybean plants. Plant Health Progress 16 (3): 118-122. doi:10.1094/PHP-RS-15-0020

Petrović, K. (2012). Morphological, molecular and pathogenic characterization of species Diaporthe/Phomosis on soybean in Serbia. Doctoral dissertation, University of Belgrade, Faculty of Agriculture.

Petrović, K., Vidić, M., Riccioni, L., Đorđević, V. \& Rajković, D. (2015) First report of Diaporthe eres species complex causing seed decay of soybean in Serbia. Plant Disease 8 (99): 1186.

Petrović, K., Riccioni, L., Vidić, M., Đorđević, V., Balešević-Tubić, S., Đukić, V. \& Miladinov, Z. (2016). First report of Diaporthe novem, $D$. foeniculina and D. rudis associated with soybean seed decay in Serbia. Plant Dis, 100 (11): 2324.

Rekab, D., Del Sorbo, G., Reggio, C., Zoina, A. \& Forrao, G. (2004). Polymorphisms in nuclear rDNA and mtDNA reveal the polyphyletic nature of isolates of Phomopsis pathogenic to sunflower and a tight monophyletic clade of defined geographic origin. Mycology Research, 108 (4): 393-402.

Roy, K.W., Ratnayake, S. \& McLean, K. (1997). Colonization of weeds by Phomopsis longicolla. Canadian Journal of Plant Pathology, 19: 193196.

Sanogo, S. \& Etarock, B.F. (2009). First report of Phomopsis longicolla causing stem blight of valencia peanut in New Mexico. Plant Disease, 93: 965.

Santos, J.M., Correia, V.G. \& Phillips, A.J.L. (2010). Primers for mating-type diagnosis in Diaporthe and Phomopsis: their use in teleomorph induction in vitro and biological species definition. Fungal Biology, 114: 255-270.

Santos, J.M., Vrandečić, K., Ćosić, J., Duvnjak, T. \& Phillips, A.J.L. (2011). Resolving the Diaporthe species occurring on soybean in Croatia. Persoonia 27: 9-19.
Sinclair, J.B. (1993). Phomopsis seed decay of soybeans - a prototype for studying seed decay. Plant Disease, 77: 329-334.

Shu, C., Chen, J., Huang, H., He, Y. \& Zhou, E. (2014). First report of Phomopsis longicolla causing stem canker of eggplant in Guangdong, China. Plant Disease, 98: 426.

Sun, X., Guo, L.D., Hyde, K. D. (2011). Community composition of endophytic fungi in Acer truncatum and their role in decomposition. Fungal Divers, 47: 85-95.

Van Niekerk, J.M., Groenewald, J.Z., Farr, D.F., Fourie, P.H., Halleen, F. \& Crous, P.W. (2005). Reassessment of Phomopsis species on grapevines. Australasian Plant Pathology, 34: 27-39.

Van Rensburg, J.C.J., Lamprech, T.S.C., Groenewald, J.Z., Castlebury, L.A. \& Crous, P.W. (2006). Characterization of Phomopsis spp. associated with die-back of rooibos (Aspalathus linearis) in South Africa. Studies in Mycology, 55: 65-74.

Vidić, M., Jasnić, S. (1994). Phomopsis vrste na soji u Jugoslaviji. Zbornik rezimea III jugoslovenskog kongresa o zaštiti bilja, Vrnjačka Banja, pp. 38.

Vidić, M., Jasnić, S. \& Stojšin, V. (1996). Cultural and morphological characteristic of Phomopsis sojae and Phomopsis longicolla originating from soybean. Zaštita Bilja, 215: 37- 44.

Vidić, M. Petrović, K., Đorđević, V. \& Riccioni, L. (2013). Occurrence of Phomopsis longicolla $\beta$ conidia in naturally infected soybean. Journal of Phytopathology, 161: 470-477. https:// doi.org/10.1111/jph.12092

Vrandečić, K., Ćosić, J., Riccioni, L., Duvnjak, T. \& Jurković, D. (2004). Phomopsis longicolla - new pathogen on Abutilon theophrasti in Croatia. Plant Pathology, 53: 251.

Zhang, A.W., Hartman, G.L., Riccioni, L, Chen, W.D., Ma, R.Z. \& Pedersen, W.L. (1997). Using PCR to distinguish Diaporthe phaseolorum and Phomopsis longicolla from other soybean fungal pathogens and to detect them in soybean tissues. Plant Disease, 81: 1143-1149.

Zhang, A.W., Riccioni, L., Pedersen, W. L., Kollipara, K. \& Hartman, G.L. (1998). Molecular identification and phylogenetic grouping of Diaporthe phaseolorum and Phomopsis longicolla isolates from soybean. Phytopathology, 88: 1306-1314.

Zhang, A.W., Hartman, G.L., Curio-Penny, B., Pedersen, W.L. \& Becker, K.B. (1999). Molecular detection of Diaporthe phaseolorum and Phomopsis longicolla from soybean seeds. Phytopathology, 89: 796 -804 .

\section{Diaporthe pseudolongicolla - novi patogen na semenu soje u Srbiji}

\section{Kristina Petrović · Luca Riccioni - Vuk Đorđević · Svetlana Balešević Tubić · Jegor Miladinović · Marina Ćeran · Dragana Rajković}

Sažetak: Trulež semena je jedna od najvažnijih bolesti soje (Glycine max (L.) Merr.), koja negativno utiče na vrednost soje na tržištu. Najčešće je uzrokuje Diaporthe longicolla, zajedno sa drugim Diaporthe vrstama. Pregledom zdravstvenog stanja semena soje u Vojvodini (Srbija) uočena je morfološka varijabilnost između izolata identifikovanih kao $D$. longicolla. Upotrebom sekvenci DNK iz ITS regiona (ITS1-5.8S-ITS2) i elongacionog faktora 1-alfa (EF1- $\alpha$ ) potvrđeno je prisustvo nove vrste na semenu soje. BLAST analizom je dokazana identičnost od $100 \%$ sa $D$. psendolongicolla (sin. D. novem) koja je opisana u ovom radu i čija taksonomska revizija se razmatra. Ispitivanja patogenosti su pokazala da su obe vrste, D. longicolla i $D$. pseudolongicolla, visoko patogene na stablu i semenu soje uzrokujući $100 \%$ uvenuće biljaka kao i trulež više od $82 \%$ semena.

Ključne reči: $D$. pseudolongicolla, D. longicolla, Diaporthe, soja, trulež semena 